\title{
Incorporating drama techniques in the language classroom: Report on the „Drama in Education Days 2016“ conference in Reutlingen
}

\section{Eva Göksel Stefanie Giebert}

\begin{abstract}
The "Drama in Education Days" conference is conceived as a forum for foreign and second language teachers from all walks of education, from primary to tertiary, regardless of which language they teach. The bilingual (English and German) conference has taken place twice, in June 2015 and in July 2016. This year's conference was organised by Stefanie Giebert (now at Konstanz University of Applied Sciences) and Eva Göksel (Center for Oral Communication at the University of Teacher Education Zug, Switzerland). The twoday event provides a networking and learning space for practitioners of drama in education - veterans and newcomers alike. This year's conference took place July $23^{\text {rd }}$ and 24th at Reutlingen University in Germany and focused on contemporary applications of Drama in Education (DiE) such as: troubleshooting barriers to drama in diverse classrooms, analysing specialised and literary texts in the second/foreign language classroom and promoting stronger communication skills through improvisation. The following report details the individual workshops and shares some of the insights acquired by the conference organisers.
\end{abstract}

\section{Drama in Education for every teacher}

In order to make the conference accessible to newcomers to the field of DiE, an introductory workshop explored simple ways to incorporate drama in the language classroom. Starting with awareness and teambuilding warm-ups, Eva Göksel led the group through a sample lesson, using a series of drama conventions to delve into the plot and discover the characters of a Grimm fairy tale. The workshop aimed to make a series of drama conventions accessible to language teachers and to show them easy ways of incorporating drama work in their own practice. Using tableaux work, participants explored different emotions, imitation, and simple speaking and listening exercises for language learners. Participants examined their own teaching practice through the lens of 
drama: questioning if and how DiE could enhance the teaching and learning in their classroom. The question of how easily teachers can integrate drama in their classroom practice without formal drama training was also a hot topic, which continued to be discussed throughout the conference.

\section{Process Drama: Using fiction to learn about reality}

The conference began with an introduction to process drama and an exploration of how it could be applied to language teaching. Dr. Nicola Abraham from the Royal Central School of Speech and Drama at the University of London specialises in integrating digital technologies within process drama workshops with a wide range of community groups, not all of whom are native English speakers. Abraham shared experiences of her work as an applied theatre practitioner within the UK and abroad, where process drama brought difficult groups closer together and allowed shy or marginalised participants to have a voice. The participants were encouraged to consider if process drama in the language classroom could therefore also create space for every student's voice.

Abraham listed examples illustrating how drama in education can be used in many different situations, including with refugees, students with behavioural challenges, and learners of English as an additional language (EAL).

Practitioners have had to adapt their practice to meet the complex needs of the children and young people they work with, providing them with safe, creative, learning spaces. With her talk "Contemporary Applications of Drama in Education: Troubleshooting Barriers to Drama in Diverse Classrooms" Abraham addressed concerns about using drama with challenging groups - including the challenge of engaging learners who are struggling with the subject matter, such as may be the case in a second/foreign language classroom. In response to the concern of a teacher losing status and or control of the class by working with a somewhat chaotic form of drama, Abraham cited examples of work done in UK schools were youth experiencing challenges with authority were able to find ways to work together respectfully through process drama.

The talk was followed up with two process drama workshops in which participants took an active part. "Pirates" explored the concepts of building group dynamics and learning to collaborate as a team: the group learned to rely on their own resourcefulness and to see themselves as "experts" in their own right, while creating shared memories during the "journey" across a desert island. This particular process drama was designed for a group of challenging students who were having difficulty creating friendships within their class. After going through the process drama, the group experience was deconstructed to examine ways of facilitating 'in-role' work in order to maintain behaviour management and to ensure learning outcomes are met.

The second workshop took participants to the land of Oz to explore fictional events (the history of $\mathrm{Oz}$ ) and ethical dilemmas. Drawing upon Dorothy Heathcote's Mantel of the Expert and Cecily O'Neill's Process Drama, this session placed the teacher in role as a 'guide' for the action on stage. The process 
drama aimed to explore marginalisation and difference and is appropriate for groups aged 16 and older.

\section{Using non-fictional texts in DiE in foreign language teaching}

In their workshop, Andrea Knupfer, Staatliches Seminar für Didaktik und Lehrerbildung Stuttgart and Kathrin Klaschik, Louis-Leitz-Schule Stuttgart, used drama to access non-fictional foreign language texts. Based on the premise that decoding a non-fictional text is a cognitive challenge for most students, the workshop leaders explored alternative, hands-on approaches to these texts, such as by playing with rhythm, soundscapes and tableaux. The focus lay on making texts, which students often consider to be dry and drab, tangible, understandable and meaningful through the use of drama tools.

\section{Improvising to improve communicative language skills}

In his workshop, Tomáš Andrášik, from Masaryk University, Brno, in the Czech Republic, led participants through a series of improvisation exercises and demonstrated their use in the language classroom to develop a fun, positive atmosphere and to build a sense of team spirit. In addition, Andrášik maintained that improv exercises allow for creativity and provide room for the unexpected - excellent for language practice. As the participants experienced firsthand, mastering improvisation techniques can help

lower communicative anxiety and to build self-confidence, especially in speaking and listening. This was demonstrated by an exercise for practicing the past tense. The narrator shares the events of the previous day with a partner, who asks the narrator to embellish the tale by asking him/her to "exaggerate" or to "lie". Andrášik also showed examples of how improv can empower spontaneous and authentic communication and offer opportunities to practice language for real-life situations.

\section{Drama Grammar in practice}

In this interactive workshop, Dr. Stefanie Giebert, from Reutlingen University, provided a brief overview of a phase model of drama grammar as outlined by Susanne Even. Giebert then encouraged participants to explore the concept in the context of their own teaching. Working in small groups, the participants developed small scenes (in their target language) depicting an embarrassing moment in the past. In order to practice a grammatical structure, the scenes were commentated by a narrator using the past tense and shared with the group. 


\section{Summary}

35 participants from 8 countries took part in the "Drama in Education Days 2016." A PhD colloquium at the end of the first day was well attended. 6 $\mathrm{PhD}$ candidates from Germany, the Czech Republic, Luxembourg, Italy and Switzerland, briefly presented their research in topics such as applying drama in education in teacher training and in multilingual classes. In a last reflection round on the second day, participants shared their experiences of the two-day event. The necessity of engaging wholeheartedly in a process drama in order for to ensure its success was discussed; the magic only works if the workshop leader commits one hundred percent along with the participants. In addition, some participants wished for a more in-depth discussion of the relevance and potential of Process Drama work in language teaching. Participants also felt that the importance of time (i.e. making time for drama) should be discussed: the consensus was that although it takes time to move tables and chairs to make room for drama work, that time is won back in terms of what the learner's achieve and experience during class.

The session ended with open questions about evaluation: can teachers measure success in drama work? How can it be graded? In what ways can teachers make sure their (drama) work is taken seriously by parents and by the school? Participants were left to ponder a professional challenge: how could they best integrate drama work in their own classrooms? The question is a complex one and surely merits to be explored during a future Drama in Education Day. 